\section{'LA Early': A New Early Marketing Satsuma Mandarin}

\author{
W.J. Bourgeois ${ }^{1}$, R.J. Constantin ${ }^{2}$, and M.J. Falcon ${ }^{3}$ \\ Louisiana State University, AgCenter, Citrus Research Station, Louisiana \\ Agricultural Experiment Station, 22193 Highway 23, Port Sulphur, \\ LA 70083
}

Additional index words. citrus, cultivar development, satsuma mandarin, Citrus unshiu

'LA Early' (Fig. 1), a new early maturing satsuma mandarin cultivar (Citrus unshiu Marcovitch), is a product of the Louisiana State Univ. (LSU) AgCenter citrus research program. The objective of the program is to develop fresh market lines of citrus fruits (navels, satsumas, and other cultivars) with improved quality, fruit characteristics, and production (Bourgeois et al., 1993, 1995; Brown et al., 1976; Reuther et al., 1967). 'LA Early', field tested as 'LA3-3', is an improved quality satsuma mandarin that ripens in early September to mid-October.

\section{Origin}

'LA Early' is an open-pollinated cultivar of unknown satsuma mandarin parentage. It was selected in the early 1980s from a group of seedlings planted in the late 1960s by the late Ralph Brown, first superintendent of the Citrus Research Station in Port Sulphur, La.

\section{Description}

Fruit characteristics. 'LA Early' produces medium to large fruit, oblate in shape, and with greater yield than 'Early Armstrong' (Table 1). Fruit weight and diameter of 'LA Early' are slightly larger than 'Early Armstrong'. 'LA Early' has a light yellow, thin, leathery skin with an attractive appearance. Skin adherence is slight to moderate, but still easy to peel. Fruit puffiness ranges from none to slight. Flesh color is orange and slightly more intense than 'Early Armstrong'. The flesh is tender and melting with easily separated segments. Fruits are essentially seedless. Taste and flavor are excellent with fruits being juicy and slightly acid. Overall quality is higher than 'Early Armstrong' (Table 1).

Foliage characteristics. Leaves are dark green, large $(7.6-10.2 \mathrm{~cm}$ long and 2.5-5.1 $\mathrm{cm}$ wide), lanceolate, tapering at the base and apex, and have a thin petiole.

Tree characteristics. 'LA Early' trees are medium in size but very productive. The growth habit is similar to 'Early Armstrong'

\footnotetext{
Received for publication 1 May 2002. Accepted for publication 19 Nov. 2001. Approved for publication by the Director of the Louisiana Agricultural Experiment Station as manuscript No. 01-82-0212. ${ }^{1}$ Professor.

${ }^{2}$ Professor and Resident Director.

${ }^{3}$ Former Research Associate.
}

HortScience, Vol. 37(6), OCtober 2002

Fig. 1. 'LA Early' satsuma. Apr. 1992 at Port Sulphur, La.

${ }^{y}$ Fruit weight: Average of five fruit/plot (4 reps). sectioned (4 reps). $\mathrm{C} 32$ = Citrange $\mathrm{C} 32$. range test 0.05 ). evaluation indicates that 'La Early' harvest can occur from early September into midOctober, slightly ahead of 'Early Armstrong' (Table 3).

\section{Recommendations}

'LA Early' has performed well for several years in experimental trials at the Citrus Research Station in Louisiana. This cultivar is not intended to replace any existing cultivar but to complement early marketing of improved satsuma mandarins. Several factors that warrant attention in production of this cultivar are: 1) fruit susceptibility to brown rot (Phytophthora citrophthora) just prior to harvest which will require control measures; 2) fruit susceptibility to attack from the leaf-footed plant bug (Leptoglossus phyllopus) will require scouting and control

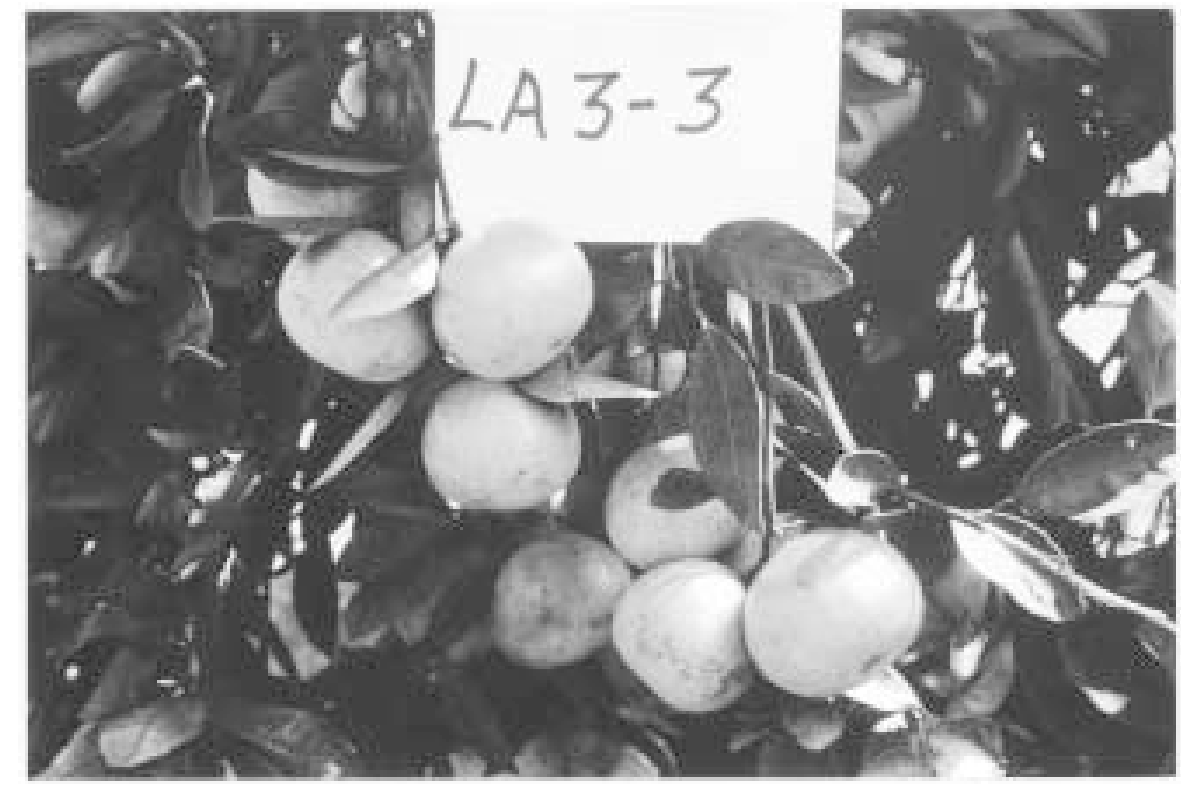

Table 1. Average yield and fruit quality of early maturing satsuma cultivars from 1993-2000. Planted:

\begin{tabular}{lcccccccc}
\hline \hline & $\begin{array}{c}\text { Yield }^{\mathrm{z}} \\
(\mathrm{kg} / \text { tree })\end{array}$ & $\begin{array}{c}{\text { Fruit } \mathrm{wt}^{\mathrm{y}}}_{(\mathrm{g})} \\
\text { Cultivar }\end{array}$ & $\begin{array}{c}\text { Fruit } \\
\text { diam }^{\mathrm{x}} \\
(\mathrm{cm})\end{array}$ & $\begin{array}{c}\text { Rind } \\
\text { thickness }^{\mathrm{w}} \\
(\mathrm{mm})\end{array}$ & $\begin{array}{c}\text { Juice } \\
\mathrm{pH}\end{array}$ & $\begin{array}{c}\text { Juice } \\
(\%)\end{array}$ & $\begin{array}{c}\text { Soluble } \\
\text { solids }^{\mathrm{v}} \\
(\%)\end{array}$ & $\begin{array}{c}\text { Solids : acid } \\
\text { ratio }^{\mathrm{u}}\end{array}$ \\
\hline Early Armstrong-R & $41.3 \mathrm{c}^{\mathrm{s}}$ & $153.3 \mathrm{a}$ & $7.14 \mathrm{a}$ & $2.6 \mathrm{a}$ & $4.2 \mathrm{a}$ & $41.5 \mathrm{a}$ & $6.9 \mathrm{~b}$ & $12.8 \mathrm{~d}$ \\
LA Early-R & $52.1 \mathrm{~b}$ & $154.0 \mathrm{a}$ & $7.24 \mathrm{a}$ & $2.4 \mathrm{~b}$ & $4.3 \mathrm{a}$ & $41.5 \mathrm{a}$ & $7.4 \mathrm{a}$ & $14.8 \mathrm{ab}$ \\
LA Early-S & $75.4 \mathrm{a}$ & $164.2 \mathrm{a}$ & $7.37 \mathrm{a}$ & $2.4 \mathrm{~b}$ & $4.4 \mathrm{a}$ & $43.2 \mathrm{a}$ & $7.4 \mathrm{a}$ & $14.0 \mathrm{a}-\mathrm{c}$ \\
LA Early-C35 & $71.9 \mathrm{a}$ & $161.8 \mathrm{a}$ & $7.29 \mathrm{a}$ & $2.4 \mathrm{~b}$ & $4.3 \mathrm{a}$ & $40.3 \mathrm{a}$ & $7.3 \mathrm{a}$ & $14.4 \mathrm{a}-\mathrm{c}$ \\
LA Early-C32 & $79.4 \mathrm{a}$ & $160.3 \mathrm{a}$ & $7.32 \mathrm{a}$ & $2.4 \mathrm{~b}$ & $4.3 \mathrm{a}$ & $43.8 \mathrm{a}$ & $7.0 \mathrm{~b}$ & $13.6 \mathrm{c}$ \\
\hline
\end{tabular}

${ }^{2}$ Yield: Represents means of 4 reps at 2 trees/scion/rootstock/plot.

${ }^{x}$ Fruit diameter: Measuring by placing a caliper over the apex of five fruit/plot (4 reps).

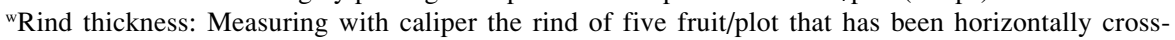

'Soluble solids: Determined by applying blended juice of five fruit/plot to a hand held brix refractometer. "Solids acid ratio: Titration of juice sample with $0.1 \mathrm{~N} \mathrm{NaOH}$ to determine titratable acid then calculating the solids : acid ratio using the following $\mathrm{S} / \mathrm{A}=$ soluble solids divided by titratable acid.

'Letter refers to rootstock upon which trees were budded: $\mathrm{R}=$ Rubidoux; $\mathrm{S}=$ Swingle; $\mathrm{C} 35$ = Citrange C35;

s Means within columns followed by the same letter are not significantly different (Duncan's multiple 
Table 2. Soluble solids and solids : acid ratio as fruit maturity indicators of early satsuma cultivars for two seasons at Port Sulphur, La.

\begin{tabular}{lccccc}
\hline \hline & \multicolumn{3}{c}{ Maturity evaluation factors } \\
\cline { 2 - 3 } \cline { 5 - 6 } Cultivar & \multicolumn{2}{c}{ Soluble solids (\%) } & & \multicolumn{2}{c}{ Solids : acid ratio } \\
\cline { 2 - 3 } \cline { 5 - 6 } & $9 / 24 / 99$ & $9 / 8 / 00$ & & $9 / 24 / 99$ & $9 / 8 / 00$ \\
\hline Early Armstrong-R ${ }^{z}$ & 7.5 & 7.5 & & 9.7 & 8.9 \\
LA Early-R & 8.5 & 8.0 & & 14.6 & 12.4
\end{tabular}

${ }^{\text {zLetter refers to the rootstock upon which trees were budded: } \mathrm{R}=}$ 'Rubidoux'.

measures; and 3) heavy fruit set can occur, resulting in reduced individual fruit size. 'LA Early' has performed well on various rootstocks such as Poncirus trifoliata 'Rubidoux', Swingle citrumelo, and Citranges C35 and C32. 'LA Early' is recommended for commercial and home planting of early market satsumas in Louisiana's citrus growing areas.

Table 3. Fruit maturity range of satsuma cultivars.

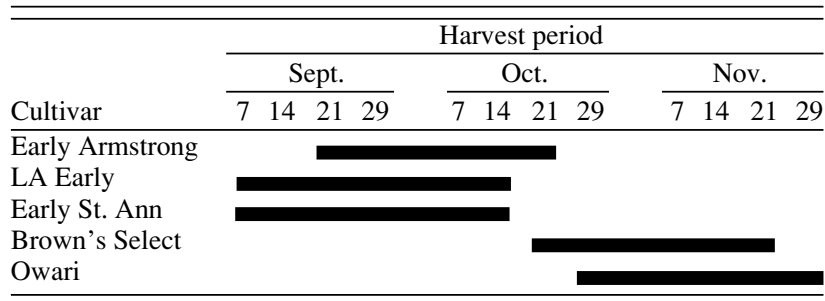

\section{Availability}

Limited quantities of budwood will be available from the LSU AgCenter Citrus Research Station, 22193 Highway 23, Port Sulphur, LA 70083.

\section{Literature Cited}

Bourgeois, W.J., R.J. Constantin, and A.J. Adams. 1993. 'Brown's Select': A new mid season satsuma cultivar. LSU Agr. Ctr., Louisiana Agr.
Expt. Sta. Circ. No. 133.

Bourgeois, W.J., R.J. Constantin, and A.J. Adams. 1995. 'Brown's Select': A new midseason satsuma cultivar. HortScience 30:391-392.

Brown, R.T., P.L. Hawthorne, J.E. Love, D.W Newsom, and T.J. Raiford. 1976. Kimbrough: A new cold hardy satsuma variety. LSU Agr. Expt. Sta. Circ. No. 102.

Reuther, W., H.J. Webber, and L.D. Batchelor. 1967. The citrus industry, history, world distribution, botany and varieties. Volume 1. Univ. of California. 